\title{
Effects of dry period length and concentrate protein content in late lactation on body condition score change and subsequent lactation performance of thin high genetic merit dairy cows
}

\author{
A. J. Dale, ${ }^{*}$ P. J. Purcell, ${ }^{*}$ A. R. G. Wylie, ${ }^{*}$ A. W. Gordon, $†$ and C. P. Ferris ${ }^{* 1}$ \\ *Sustainable Agri-Food Sciences Division, Agri-Food and Biosciences Institute, Large Park, Hillsborough, County Down, \\ Northern Ireland BT26 6DR \\ †Biometrics and Information Systems Branch, Agri-Food and Biosciences Institute, AFBI Headquarters, 18a Newforge Lane, Belfast, \\ Northern Ireland BT9 5PX
}

\begin{abstract}
Improving body condition score of thin cows in late lactation is necessary, because cows that are thin at drying off exhibit decreased fertility postpartum and are at increased risk of disease and of being culled in the subsequent lactation. Offering a diet low in crude protein (CP) content in late lactation may help to improve body condition score (BCS) at drying off, whereas imposing an extended dry period (EDP) has been advocated as another way to increase BCS at calving. To test these hypotheses, 65 thin cows (mean BCS 2.25 at 14 wk precalving) were managed on 1 of 3 treatments between 13 and 9 wk prepartum: normal protein control $\{\mathrm{NP}$; grass silage $+5 \mathrm{~kg} / \mathrm{d}$ of a normal protein concentrate $[228 \mathrm{~g}$ of $\mathrm{CP} / \mathrm{kg}$ of dry matter $(\mathrm{DM})]\}$, low protein [LP; grass silage $+5 \mathrm{~kg} / \mathrm{d}$ of a lowprotein concentrate $(153 \mathrm{~g}$ of $\mathrm{CP} / \mathrm{kg}$ of $\mathrm{DM})]$, or $\mathrm{EDP}$ (cows dried off at $13 \mathrm{wk}$ precalving and offered a grass silage-only diet). Both NP and LP cows were dried off at wh 8 prepartum, after which all cows were offered a grass silage-only diet until calving. After calving, all cows were offered a common diet (supplying $11.1 \mathrm{~kg}$ of concentrate DM/cow per day) for 19 wk. Between 13 and 9 wk prepartum, LP cows had lower DM intake, milk yield, and body weight than NP cows. Whereas EDP cows had lower serum $\beta$-hydroxybutyrate and fatty acid concentrations than those of NP cows, BCS at wk 9 prepartum did not differ between treatments. Cows on the LP treatment continued to have lower DMI and BW than those of NP and EDP cows between 8 wk prepartum and calving, but only EDP cows had a higher BCS at calving. Treatment did not affect calving difficulty score or calf birth weight. Although all cows were offered a common diet postpartum, cows on
\end{abstract}

Received August 18, 2016

Accepted November 7, 2016.

${ }^{1}$ Corresponding author: conrad.ferris@afbini.gov.uk the LP treatment had lower DM intake and milk fat + plus protein yield than cows on any other treatment during the 19-wk period postpartum, but we found no differences in any postpartum indicator of body tissue reserves. The treatments imposed from wk 13 to 9 prepartum had no effect on any fertility or health parameters examined postpartum. Extending the dry period for thin cows improved their BCS at calving but did not allow these cows to achieve the target BCS of 2.75, and we found no beneficial effects of this treatment on cow performance postpartum. Offering a lower-protein diet to thin cows in late lactation did not improve BCS at calving above that of cows on a normal protein diet, but had unexplained long-term negative effects on cow performance.

Key words: thin cows, body condition, dry period, late lactation diet

\section{INTRODUCTION}

Most dairy cows experience a period of negative energy balance (NEB) early postpartum (pp) when their energy intake is inadequate to service the energy demands of lactation. Even well-managed cows may mobilize up to $40 \%$ of their fat reserves at this time (Chilliard et al., 2000), whereas cows that are underfed relative to requirements may incur even greater losses. Postpartum NEB is more pronounced in cows of higher genetic merit (Pryce et al., 2001) and may also be more protracted, such that cows already in poor condition in early or mid lactation can end their lactation visibly thin (i.e., with a low BCS).

Thin cows are common on many dairy farms. In a recent study of 10 dairy farms in Northern Ireland, Law et al. (2016) found that $88 \%$ of the 1,217 cows entered the dry period (DP) in low body condition (BCS $<2.5$ on a 1-5 scale). They also found that thin cows (BCS $<2.25)$ that were offered no concentrates during the dry period were at increased risk of being culled during the 
subsequent lactation. Markusfeld et al. (1997) observed that multiparous cows with a higher BCS at calving were less likely to be culled. Thin cows are more prone to peripartal health problems, including dystocia, endometritis, and retained placenta (Heuer et al., 1999; Hoedemaker et al., 2009; Roche et al., 2015), that afflict many cows at a time when their immune-competence is impaired (Sordillo, 2016). Experimental evidence has shown that thin cows are more difficult to rebreed (Pryce et al., 2000; Hoedemaker et al., 2009; Roche et al., 2009). Moreover, thin cows that do become pregnant are more susceptible to peripartal disease (Heuer et al., 1999), bringing added veterinary costs and, often, an extended calving-to-conception interval (Borsberry and Dobson, 1989). Improving the BCS of thin cows before calving is a key management objective in many dairy herds, with Garnsworthy (2007) recommending 2.75 as the optimum calving BCS for high-yielding cows.

Improving the body condition of higher-yielding cows during an 8-wk DP is challenging within Northern Ireland's grassland-based dairy systems (Law et al., 2016; Little et al., 2016a,b, 2017). Likewise, the appropriateness of a 50 to $60 \mathrm{~d}$ DP that evolved to suit loweryielding cows of a previous era, but is still widely used across the United States and Europe today, is questionable for contemporary high-genetic merit cows, and is perhaps in need of review. Consequently, interest exists in developing strategies to improve the body condition of cows in late lactation.

High-yielding cows offered additional concentrates of standard protein content in late lactation tend to partition much of the extra energy intake to milk production (Ferris and Mayne, 2003). However, in a previous study at the Agri-Food and Biosciences Institute (Hillsborough, UK), offering a low-protein diet (144 vs. $173 \mathrm{~g}$ of $\mathrm{CP} / \mathrm{kg}$ of $\mathrm{DM}$ ) to high-yielding cows in early lactation, the authors found reduced milk production and improved energy balance (EB) over the first $150 \mathrm{~d}$ of lactation without an effect on DMI (Law et al., 2009a). In a follow-up study, Gilmore et al. (2011) found that the EB of cows in early lactation was improved by shortterm reductions in protein intake. Building on this, Law et al. (2011a) showed that lower-protein diets and a slower build-up of concentrates promoted a return to a positive EB by wk $7 \mathrm{pp}$, whereas cows offered normal allocations of a standard protein concentrate took 18 wk to attain positive EB. However, no substantial evidence has shown that offering cows diets low in protein and high in energy in late lactation can improve BCS.

Extending the DP, as is commonly practiced in New Zealand's grazing-based dairy systems, is an alternative option for improving cow condition in late lactation. Whereas it is axiomatic that a longer DP reduces milk yield in that lactation, thus allowing the diversion of dietary energy to tissue gain, there is an expectation also of a higher milk yield in the next lactation. Indeed, Weber et al. (2015) found that cows given a 90-d DP produced more milk to 200 DIM in the next lactation than cows given a 28-d DP. However, cows allocated to the notional 90-d DP treatment in that study were selected because their milk yield had fallen to $<15 \mathrm{~kg} / \mathrm{d}$. In contrast, Pinedo et al. (2011) found both shorter $(<31 \mathrm{~d})$ and longer (77-250 d) DP to be negatively associated with early lactation and 305-d milk yields. However, their study also was confounded in that data were taken from retrospective herd records rather than generating data through controlled experiments. Few authors have attempted to systematically evaluate the use of planned extended DPs for dairy cows.

Few controlled studies have evaluated the effects of varying DP length or DP nutrition on cow BCS at calving and subsequent lactation performance, and fewer still have focused exclusively on cows that are already thin at drying off. The benefits for cow BCS at calving and for subsequent lactation performance, of offering thin cows a lower-protein diet in late lactation or of extending the DP markedly, are essentially unresearched and were the twin focuses of the current study.

\section{MATERIALS AND METHODS}

All animal procedures were approved by the animal research ethics committee at the Agri-Food and Biosciences Institute, Hillsborough. The experiment was conducted at Agri-Food and Biosciences Institute Hillsborough under an experimental license granted by the Department of Health, Social Services \& Public Safety for Northern Ireland, and in compliance with the United Kingdom Animals (Scientific Procedures) Act (UK Government, 1986).

\section{Pre-Experimental Management}

Commencing in mid-July 2014, a dynamic group of mid- to late-lactation, autumn-calving, Holstein-Friesian dairy cows (new cows being added as the season progressed) was managed with the objective of achieving a mean BCS of 2.25 (target range: 2.0-2.5) at wk 13 before expected calving date. Cows were grazed tightly (target postgrazing sward height $<4.5 \mathrm{~cm}$ ) and offered $3.0 \mathrm{~kg}$ concentrate each per day $(1.5 \mathrm{~kg}$ at each milking) through an in-parlor concentrate feeding system until 13 wk before their expected calving date. Cows remaining within this dynamic group on November 5 were moved indoors and offered medium-quality grass silage (ad-libitum) plus $5.0 \mathrm{~kg}$ of concentrate daily (2.5 $\mathrm{kg}$ at each milking) via an in-parlor feeding system until 13 wk before their expected calving date. 


\section{Cows and Housing}

A total of 65 cows, each with a BCS of 2.5 or less, were selected from the group described above $14 \mathrm{wk}$ before their expected calving date. Cows selected before November 5 were moved indoors at this time. Selected cows were placed in a freestall house with access to individual rubber-matted cubicles $(2.20 \times 1.25 \mathrm{~m})$. The mats were dusted with lime once weekly and the sawdust bedding was refreshed 3 times weekly. The house had a concrete floor which was scraped every $3 \mathrm{~h}$ using an automated system. Cows remained in this house for the full experimental period (13 wk precalving, until wk 19 postcalving). These cows (23 primiparous and 42 multiparous; mean parity $=2.0 ; \mathrm{SD}=0.87$ ) had a mean predicted transmitting ability for milk and milk fat-plus-protein yield of $79(\mathrm{SD}=135.9)$ and $16.7(\mathrm{SD}$ $=8.04) \mathrm{kg}$, respectively, and a mean profitable lifetime index (PLI) of $£ 219$ (SD = 91.9) (December 2015 proof run).

\section{Treatments}

Cows were allocated to 1 of 3 treatments 13 wk before their expected calving date, at which time they had a mean BCS of $2.25(\mathrm{SD}=0.158)$. Cows within each treatment group were balanced for parity (1,2 and $>2$ ), BCS, BW, milk yield (during the previous week), milk composition (as recorded on 1 occasion during the previous 4 -wk period), and predicted transmitting ability for fat + protein $(\mathrm{kg})$, PLI, and their previous lactation 305-d milk yield.

We used 3 experimental treatments.

1. Normal protein (NP): ad libitum grass silage plus $5.0 \mathrm{~kg} /$ cow per day of a normal protein concentrate (target: $230 \mathrm{~g}$ of $\mathrm{CP} / \mathrm{kg}$ of $\mathrm{DM}$ ). This diet was offered from wk 13 to 9 (5-wk period) before the expected calving date for each cow. Cows were dried off 8 wk before their expected calving date.

2. Low-protein $(\mathbf{L P})$ : ad libitum grass silage plus $5.0 \mathrm{~kg} / \mathrm{cow}$ per day of a low-protein concentrate (target: $150 \mathrm{~g}$ of $\mathrm{CP} / \mathrm{kg}$ of $\mathrm{DM}$ ). This diet was offered from wk 13 to 9 (5-wk period) before the expected calving date for each cow. Cows were dried off $8 \mathrm{wk}$ before their expected calving date.

3. Extended dry period (EDP): cows were dried off 13 wk before their expected calving date and offered grass silage ad libitum without concentrate supplementation.

During wk 13 to 9 before their expected calving date, cows on the NP and LP treatments were kept in a single group, whereas cows in the EDP group were housed in a separate pen. All cows accessed the forage portion of their diet via a series of feed-boxes mounted on weighing platforms with access controlled by a Calan-gate feeding system (American Calan, Northwood, $\mathrm{NH}$ ) linked to an automatic cow identification system (Griffith Elder; Bury St. Edmunds, UK), which recorded the weight of food consumed by each cow each day. Silage for all 3 treatments was placed in a complete diet mixer wagon (Redrock, Armagh, UK) and mixed for approximately 5 min before being placed in the feed boxes. Cows on the NP and LP diets accessed their silage via separate feed boxes. Fresh silage was offered daily between 0900 and $1030 \mathrm{~h}$. Uneaten silage was removed the following day at approximately $0830 \mathrm{~h}$. The silage offered during wk 13 to 9 prepartum was produced from a combination of primary growth (harvest dates: May 16-22) and secondary regrowth of grass (harvest date: September 17). The concentrate portion of the diet (ingredient composition presented in Table 1) was offered via an in-parlor concentrate feeding system, at $2.5 \mathrm{~kg}$ of fresh weight/cow at each milking.

After drying off (at 8 wk before expected calving) cows from the NP and LP treatments joined those from the EDP treatment, and all cows were offered the same grass silage as was offered during wk 13 to 9 precalving until calving. No concentrates were offered during this period. The silage offered throughout the DP was supplemented with precalving minerals, and with additional calcined magnesite over the final $3 \mathrm{wk}$ prepartum. Both supplements were mixed with the silage.

Table 1. Ingredient composition ( $\mathrm{kg} / \mathrm{t}$, fresh basis) of the concentrates offered during the pre- and postpartum periods

\begin{tabular}{|c|c|c|c|}
\hline \multirow[b]{2}{*}{ Item } & \multicolumn{2}{|c|}{ Prepartum $^{1}$} & \multirow[b]{2}{*}{ Postpartum ${ }^{2}$} \\
\hline & Normal protein & Low protein & \\
\hline Wheat & 137 & 98 & 125 \\
\hline Maize & 98 & 293 & 170 \\
\hline Sugar beet pulp & 102 & 102 & - \\
\hline Palm kernel & - & - & 95 \\
\hline Wheat feed & - & - & 65 \\
\hline Maize gluten & - & 175 & 124 \\
\hline Soybean meal & 298 & 50 & 130 \\
\hline Soya hulls & 204 & 205 & 100 \\
\hline Rapeseed meal & 100 & - & 125 \\
\hline Maxfat $\mathrm{CS}^{3}$ & 22 & 28 & - \\
\hline Palm oil & - & - & 9 \\
\hline Molasses $^{4}$ & 17 & 21 & 30 \\
\hline Minerals $^{3}$ & 22 & 28 & 17 \\
\hline Lime No. 1 flour & - & - & 10 \\
\hline
\end{tabular}

${ }^{1}$ Concentrates offered during a 5 -wk period, commencing at $13 \mathrm{wk}$ prepartum.

${ }^{2}$ Concentrates offered during a 19-wk period postpartum.

${ }^{3}$ Trouw Nutrition, Belfast, UK.

${ }^{4}$ United Molasses Ireland Ltd., Belfast, UK. 
Target intakes for the 2 supplements were 100 and 50 $\mathrm{g} /$ cow per day, respectively.

Cows were moved to a straw-bedded maternity pen 24 to $48 \mathrm{~h}$ before their expected calving date, based on physical observations. Postcalving (normally within 12-24 h) cows were returned to the house described earlier and placed in a group comprising freshly calved cows.

\section{Postcalving Management}

All cows calved between October 16, 2014, and March 8, 2015 (mean calving date = January 9, 2015; $\mathrm{SD}=35 \mathrm{~d}$ ). Cows from all 3 treatments were offered a common diet for the first $133 \mathrm{~d}$ (19 wk) pp. The diet comprised a mixed ration of grass silage and concentrates (60:40 ratio, on a DM basis) plus $5 \mathrm{~kg} /$ cow per day of fresh weight of the same concentrates, offered via an in-parlor concentrate feeding system. The mixed ration was offered at 1.07 of the previous day's intake. The concentrates offered in-parlor were introduced into the diet incrementally over the first $9 \mathrm{~d}$ postcalving, starting at $1.0 \mathrm{~kg} / \mathrm{d}$ immediately pp and increasing to $5.0 \mathrm{~kg} / \mathrm{d}$ at d $9 \mathrm{pp}$. The mixed ration portion of the diet was prepared daily using a complete diet mixer wagon as described previously, and was offered between 0900 and $1030 \mathrm{~h}$ each day. Cows accessed the mixed ration via the feeding system described previously. Uneaten food was removed at approximately $0830 \mathrm{~h}$ each day. The silage offered postpartum was produced from a primary grass regrowth (harvest dates $=$ July 9 and 29, 2014). The ingredient compositions of the concentrate offered is presented in Table 1.

\section{Animal Measurements}

Calving difficulty was recorded on a 1 to 4 scale as unobserved or unassisted calving (1); assisted calving without a calving aid (2); assisted calving with use of a calving aid (3); and veterinary-assisted calving (4). Calves were weighed immediately after birth. Throughout the experiment, cows were milked twice daily (between 0600 and $0800 \mathrm{~h}$ and between 1500 and $1700 \mathrm{~h}$ ) using a 50-point rotary milking parlor. Milk yields were recorded automatically at each milking, allowing total daily yield for each cow to be calculated.

Throughout the remainder of the experiment (and during the period from wk 13-9 prepartum), milk samples were collected during 2 consecutive milkings each week and analyzed for fat, protein, and lactose concentrations (Purcell et al., 2016). A weighted milk composition was calculated (based on morning and afternoon milk yields) for each 24-h sampling period. Once per month, samples from 2 consecutive milkings, combined in proportion to yield, were collected and SCS was measured using a SomaScope MK II somatic cell counter, model CA-3A4 (Delta Instruments, Drachten, the Netherlands).

Cow BW was recorded twice daily (immediately after each milking) using an automated weighbridge, and mean weekly BW was calculated for each cow. Nonlactating animals were weighed weekly before being offered fresh food between 0900 and $1030 \mathrm{~h}$. The BCS of each cow was estimated weekly by a trained technician, as per Edmondson et al. (1989), and using a 5-point scale. Milk samples for progesterone determination were taken twice weekly over the first $70 \mathrm{~d}$ pp and analyzed using an ELISA kit (Ridgeway Science, St. Briavels, UK) as described by Little et al. (2016b). This assay had a coefficient of variation of $20 \%$. The day of onset of luteal activity was defined as the first of 2 consecutive days on which milk progesterone was $\geq 3$ $\mathrm{ng} / \mathrm{mL}$. Cow AI was conducted by trained stockpersons and pregnancy was confirmed by an ultrasound scan conducted by a veterinarian. All individual cow health events and treatments were recorded. All incidences of displaced abomasum, dilated cecum, decreased rumen motility, or diarrhea were recorded as a digestive upset. Cows identified with mastitis or lameness were treated by trained stockpersons.

Blood samples were taken from the coccygeal vein of each cow before feeding in wk 9,6 , and 3 prepartum $( \pm 3 \mathrm{~d})$, and wk 2, 4, 6, 8, and $10( \pm 3 \mathrm{~d})$ postpartum, into evacuated tubes (BD, Oxford, UK) coated with either a clot activator or fluoride oxalate. Serum and plasma were recovered by centrifugation $(1,800 \times g$, $17^{\circ} \mathrm{C}, 30 \mathrm{~min}$ ) and stored at $-20^{\circ} \mathrm{C}$ until analyzed on an Auto Diagnostics Sapphire 800 autoanalyzer (Glenbio, Toome, UK) using validated kits for glucose and urea (Auto Diagnostics, Cork, Ireland), BHB (Pointe Scientific, Canton, MI), fatty acids (Wako Chemicals, Neuss, Germany), and haptoglobin (Tridelta, Maynooth, Ireland) with coefficients of variation of $0.7,3.2,1.7,1.5$, and $5.3 \%$ respectively.

\section{Feed Analysis}

Daily grass silage samples were dried at $85^{\circ} \mathrm{C}$ for 18 $\mathrm{h}$ to determine oven DM content. Twice weekly subsamples of dried samples were milled to pass a $0.8-\mathrm{mm}$ sieve, and 28-d composites were analyzed for NDF, ADF, and ash as described by Purcell et al. (2016). Samples of the concentrate feeds were taken every 14 $\mathrm{d}$ and dried at $100^{\circ} \mathrm{C}$ for $24 \mathrm{~h}$ before milling to pass a $0.8-\mathrm{mm}$ sieve and combining into 28-d composites for analysis for NDF, ADF, ash, $\mathrm{CP}(\mathrm{N} \times 6.25)$, and gross energy concentrations. An additional 14-d sample was dried at $60^{\circ} \mathrm{C}$ for $48 \mathrm{~h}$ and milled to pass a $0.5-\mathrm{mm}$ 
sieve for starch analysis by Megazyme kit (Megazyme International, Bray, Ireland). This starch assay has a repeatability relative standard deviation of $3.1 \%$. Fresh silage samples were analyzed weekly for $\mathrm{CP}$, ammonia$\mathrm{N}\left(\mathrm{NH}_{3}-\mathrm{N}\right)$, gross energy, and $\mathrm{pH}$ and for lactic and acetic acids, ethanol, and propanol (Purcell et al., 2016). Fresh silage ME concentrations were predicted by NIRS according to Park et al. (1998).

\section{Statistical Analysis}

Mean daily EB (MJ/cow per day) was calculated as described by Little et al. (2016b). Data for milk production and composition, BW, BCS, and DMI were analyzed within 3 distinct periods, namely wk 13 to 9 prepartum, wk 8 to 1 prepartum, and wk 1 to 19 postpartum. These data were analyzed using ANOVA. Appropriate pre-experimental data were included as covariates in the model when analyzing corresponding dependent variables, namely milk yields recorded during wk 14 and 15 prepartum (for milk yield), milk composition recorded on one occasion during the 4 -wk period before the start of the experiment (for milk composition), and mean BW and BCS recorded during the 2-wk period before the start of the experiment (for BW and BCS). In the case of total DMI, pre-experimental BW was used as a covariate, as pre-experimental intake data were unavailable. In addition, parity $(1,2$, and $>2$ ) was also included as a factor within the analysis. For variables for which treatment had a significant effect $(P<0.05)$, differences between treatments were tested using Fisher's-protected adjusted comparisons. Sixty-five cows were allocated to the late-lactation treatments and remained on the study throughout the period from wk 13 prepartum to calving. Five cows did not complete the 133-d pp period, with 4 being removed from the study immediately pp due to issues unrelated to the treatments (fatal digestive upset, $\mathrm{n}=1$; and calving injury, $\mathrm{n}=3$ ). One cow was removed from the study at $68 \mathrm{~d}$ pp due to a leg injury that resulted in poor locomotion. Postpartum data for these cows were treated as missing values in the analysis. Data for calving difficulty, calf birth weight, calving interval, days to onset of corpus luteum (CL) activity, and the maximum progesterone concentration during the first CL were analyzed using ANOVA, with the model including parity as a covariate. Binomial data relating to the health and fertility parameters were analyzed using a regression model, with the model including parity as a covariate. Weekly data for mean daily milk yield, mean BW, mean BCS, and mean total daily DMI were analyzed by REML analysis, using the same covariates as used previously for ANOVA analyses, with weekly measurements included as the repeated measure in the model. Parity $(1,2$ and $>2)$ and the corresponding pre-experimental covariate, as described above (for milk yield, BW, BCS, and intake), were included in the model. The model for REML analysis included the effects of late-lactation treatment, week (either prepartum or postpartum), and treatment $\times$ week, with data for each of the 3 experimental periods described above analyzed separately. Weekly data for prepartum serum and plasma biochemistry were analyzed by ANOVA for individual weeks (wk 9, 6, and 3 prepartum), with the postpartum data analyzed using REML (wk 2, 4, 6, 8, and 10$)$, with parity $(1,2$, and $>2)$ used as a covariate and using the REML model described above. All data were analyzed using GenStat Version 16.2 (VSN International, Hemel Hempstead, UK) as described by Payne et al. (2013).

\section{RESULTS}

\section{Diet Composition}

The NP concentrate had protein and starch contents of 228 and $207 \mathrm{~g} / \mathrm{kg}$ of DM, respectively, whereas the corresponding values for the LP concentrate were 153 and $293 \mathrm{~g} / \mathrm{kg}$ of DM (Table 2). The concentrate offered postpartum had average CP and starch contents of 215 and $245 \mathrm{~g} / \mathrm{kg}$ of DM, respectively. Mean volatile corrected $\mathrm{DM}, \mathrm{CP}$, and $\mathrm{ME}$ concentrations of the silage offered prepartum were $235 \mathrm{~g} / \mathrm{kg}$ of fresh weight $(\mathbf{F W})$, $130 \mathrm{~g} / \mathrm{kg}$ of DM, and $10.9 \mathrm{MJ} / \mathrm{kg}$ of DM, respectively, whereas the corresponding values for the silage offered postpartum were $326 \mathrm{~g} / \mathrm{kg}$ of $\mathrm{FW}, 119 \mathrm{~g} / \mathrm{kg}$ of DM, and $11.4 \mathrm{MJ} / \mathrm{kg}$ of DM. The diets offered between wk 13 and 9 prepartum to cows on the NP, LP, and EDP treatments had mean CP contents of 158,137 , and 130 $\mathrm{g} / \mathrm{kg}$ of DM, respectively, whereas the NP and LP diets had starch contents of 60 and $92 \mathrm{~g} / \mathrm{kg}$ of DM, respectively. The mean CP content of the postpartum diets was $165 \mathrm{~g} / \mathrm{kg}$ of DM.

\section{Treatment Effects During wk 13 to 9 Prepartum}

Cows on the LP treatment had a lower $(P=0.004)$ silage DMI than those on the NP and EDP treatments (Table 3), whereas total DMI was lowest for the EDP treatment and highest for the NP treatment $(P<$ 0.001). Cows on NP treatment tended to have greater milk yield and milk protein content $(P=0.05$ and $P=$ 0.094 , respectively), whereas their milk had a greater fat content and they had a greater milk fat-plus-protein yield ( $P=0.003$ and 0.014 , respectively).

Cows on the LP treatment gained less BW over the 5 -wk period $(P=0.004)$ and had lower BW at wk 9 prepartum $(P=0.004)$ and the lowest mean BW dur- 
Table 2. Chemical composition of the grass silages ( $\mathrm{g} / \mathrm{kg}$ of volatile-corrected DM, unless stated otherwise) and concentrates ( $\mathrm{g} / \mathrm{kg}$ of DM) offered throughout this study (SD in parentheses)

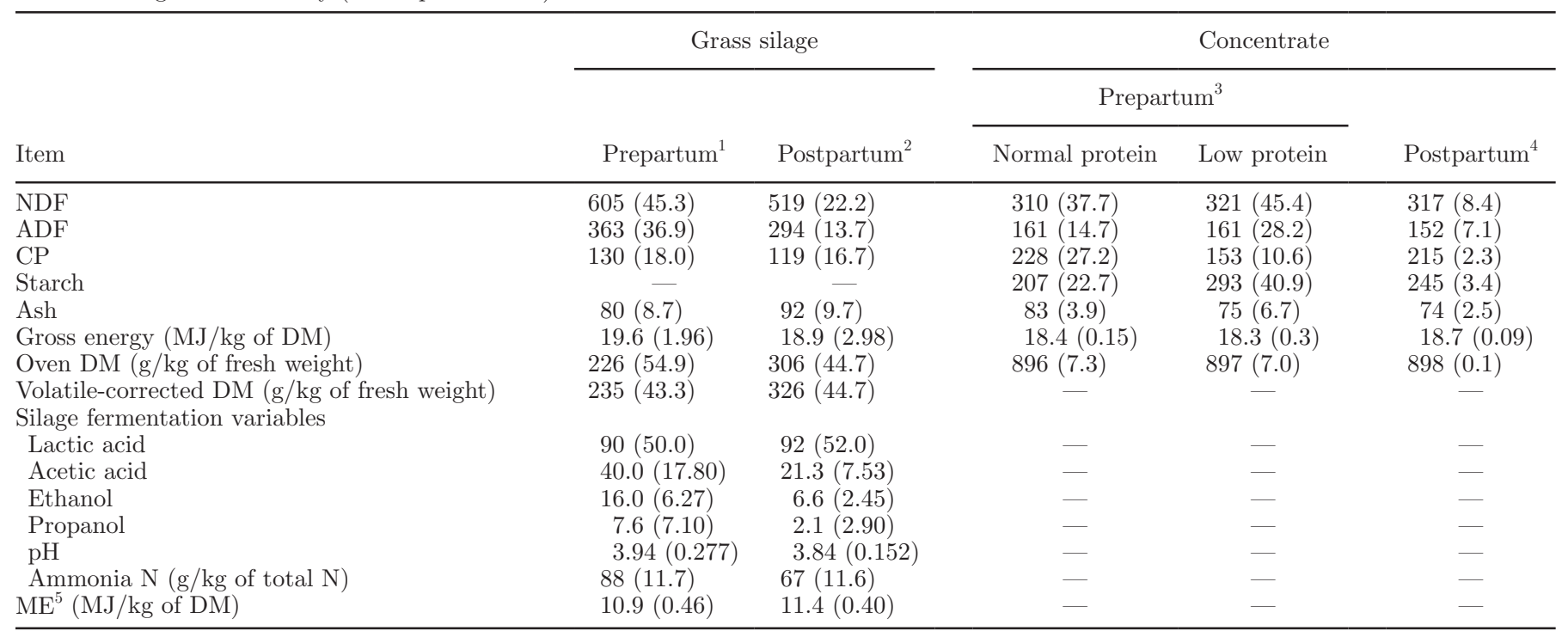

\footnotetext{
${ }^{1}$ Silage offered across all treatments throughout the 13 wk prepartum.

${ }^{2}$ Silage offered across all treatments throughout a 19 -wk period postpartum.

${ }^{3}$ Concentrates offered during a 5 -wk period, commencing at 13 wk prepartum.

${ }^{4}$ Concentrates offered during a 19 -wk period postpartum.

${ }^{5}$ Determined using near-infrared reflectance spectroscopy.
}

ing this period $(P=0.005)$. We found no significant treatment effects on either mean BCS $(P=0.320)$ or on BCS change over the period $(P=0.103)$.

When examined using repeated measures analysis, total DMI (Figure 1), BW (Figure 2), and daily milk yield (Figure 3) changed with time during this 5 -wk period (all $P<0.001$ ), whereas BCS (Figure 4) tended to change with time $(P=0.051)$. We observed no treatment $\times$ week interaction for BCS, milk yield, or total daily DMI $(P>0.10)$. Treatment did not affect plasma glucose concentration $(P=0.266)$ at wk 9 prepartum (Figure 5), but serum BHB, fatty acid, and urea concentrations were all lower in cows on the EDP treatment than for those on the NP treatment $(P<0.001$, $P<0.001$ and $P=0.004$, respectively).

\section{Treatment Effects During wk 8 to 1 Prepartum}

During this period (i.e., the conventional dry period), cows that had been managed through late lactation on the LP treatment had lower silage DMI $(P<0.001)$ than cows managed on either the NP or EDP treatments (Table 4). Treatment did not affect BW change during this period $(P=0.588)$, but LP cows had the lowest mean $\mathrm{BW}$ during this period $(P=0.001)$ and the lowest $\mathrm{BW}$ during the final week prepartum $(P$ $=0.020)$, with the respective $\mathrm{BW}$ values of cows on the other 2 treatments being similar. Mean BCS and BCS during the final week prepartum were higher $(P=$ 0.021 and $P=0.006$, respectively) for EDP cows than for cows on the other 2 treatments.

When examined using repeated measures analysis, DMI (Figure 1) decreased $(P<0.001)$ whereas BW (Figure 2) and BCS (Figure 4) increased $(P=0.001$ and $P=0.002$, respectively) over the 8 -wk period prepartum. We found a treatment $\times$ week interaction for DMI during the 8 -wk period precalving $(P=0.027)$, with the DMI of EDP cows decreasing whereas that of both NP and LP cows remained relatively constant. A treatment $\times$ week interaction was noted during this period for $\mathrm{BW}(P=0.042)$, with the rate of $\mathrm{BW}$ increase in EDP cows slowing as these cows approached calving whereas that in NP and LP cows was maintained as they approached calving. We found no treatment $\times$ week interaction for BCS $(P=0.923)$. Treatment did not affect $(P>0.10)$ plasma glucose or serum BHB, fatty acid, urea, and haptoglobin concentrations in wk 6 or 3 prepartum (Figures 5 and 6 ).

\section{Treatment Effects During wk 1 to 19 Postpartum}

Prepartum treatment did not affect calving difficulty score $(P=0.329)$ or calf birth weight $(P=0.209)$, with the values for NP, LP, and EDP treatments being 1.4, 
Table 3. Effect of concentrate protein level in late lactation and dry period length on food intake, milk yield, milk composition, BCS, BW, and energy balance over a 5-wk period, commencing 13 wk prepartum

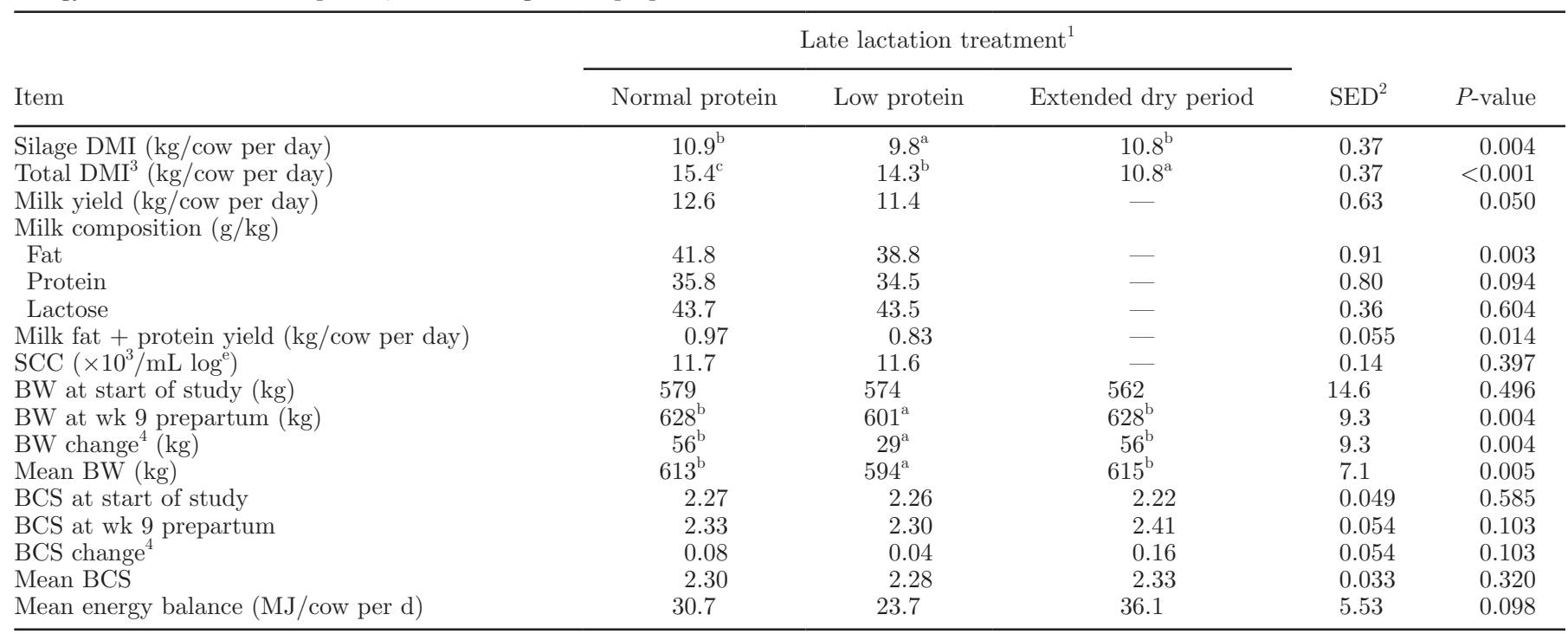

${ }^{\mathrm{a}-\mathrm{c}}$ Means with different superscripts within rows differ $(P<0.05)$.

${ }^{1}$ Treatments imposed over a 5 -wk period, commencing 13 wk prepartum.

${ }^{2}$ Standard error of the difference.

${ }^{3}$ Includes $4.49 \mathrm{~kg}$ of concentrate DM with the normal and low protein treatments.

${ }^{4}$ Change in BW and BCS between wk 13 and 9 prepartum.

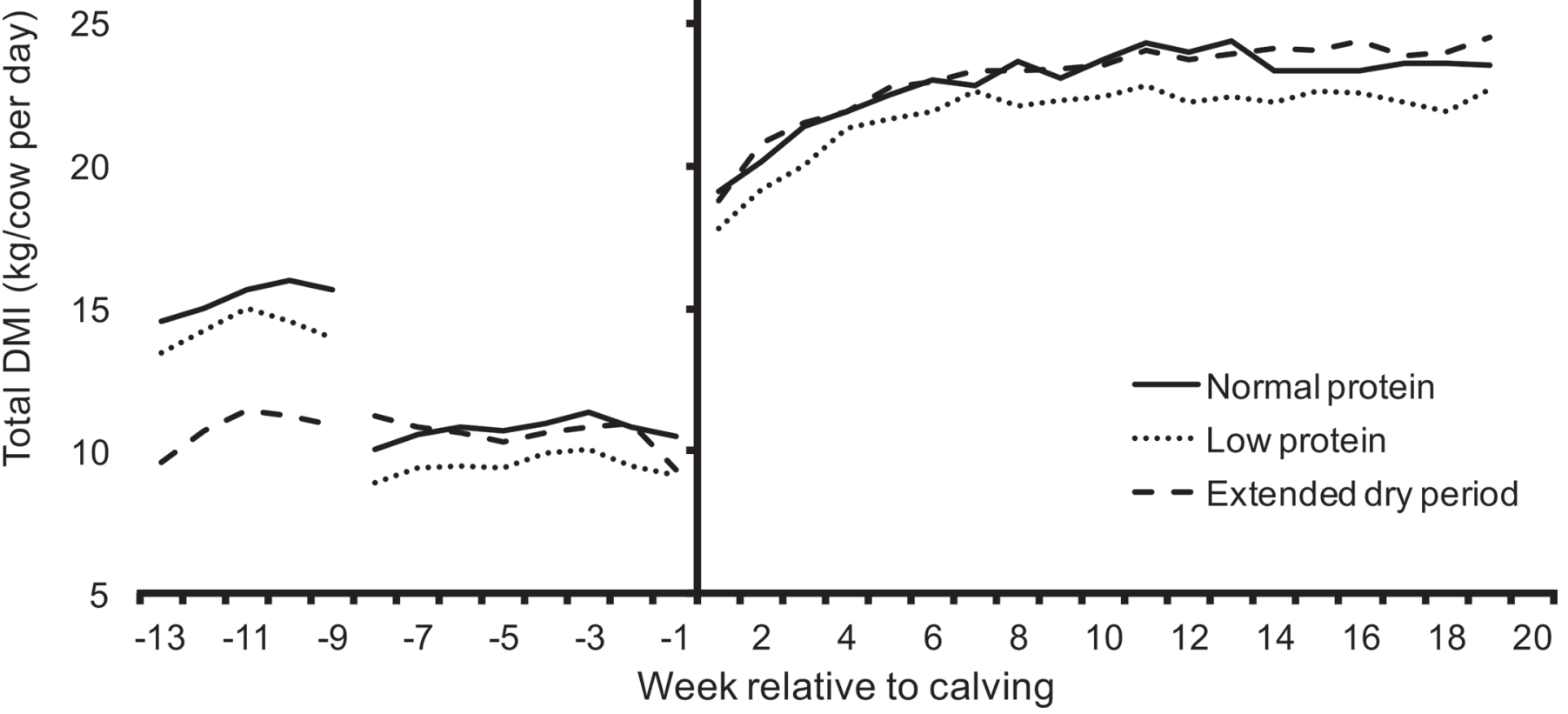

Figure 1. Effect of concentrate protein level in late lactation and dry period length on total DMI throughout the experiment. Main effects of treatment, week, and treatment $\times$ week interactions were noted; wk 13 to 9 prepartum: standard error of the difference $($ SED $)=0.32,0.22$, and $0.45, P$-value $<0.001,<0.001$, and 0.623 , respectively; wk 8 to 1 prepartum: SED $=0.32,0.24$, and $0.48, P$-value, $<0.001,<0.001$, and 0.027 , respectively; wk 1 to 19 postpartum: $\mathrm{SED}=0.38,0.36$, and $0.70, P$-value $<0.001,<0.001$, and 0.720 , respectively. 
1.2 , and 1.2 [standard error of the difference $($ SED $)=$ $0.18]$ and $41.4,38.6$, and $41.3 \mathrm{~kg}(\mathrm{SED}=1.83)$, respectively.

Cows on the LP treatment from wk 13 to 9 prepartum had a lower concentrate DMI $(P<0.009)$, a lower silage DMI $(P<0.017)$, and a lower total diet DMI $(P=0.010)$ than cows on either the NP or EDP treatments during the subsequent lactation (Table 5). However, EDP cows had greater wk 1 to 19 milk yields than those on the LP treatment $(P=0.040)$. The milk yield of cows on the NP treatment did not differ from those of cows on the other 2 treatments, whereas milk composition was unaffected by treatment $(P>0.1)$. Cows on the LP treatment had the lowest BW in the first week postpartum $(P=0.022)$ only, but treatment did not affect BW at wk $10(P>0.10)$ or $19 \mathrm{pp}(P=$ $0.075)$, nor did it affect mean BW through wk 1 to 19 pp $(P=0.090)$. Neither the nadir BW through wk 1 to 19 pp $(P>0.10)$, days to nadir BW $(P>0.01)$, or BW loss to nadir $(P=0.081)$ were affected by treatment. Nadir EB was unaffected by treatment, with mean values of $-64.2,-57.2$, and $-47.6 \mathrm{MJ} / \mathrm{d}$ (mean SED = $11.55 ; P=0.363)$ for the NP, EDP, and LP treatments, respectively. The timing of the nadir $\mathrm{EB}$ also was unaffected by treatment, with mean values of $4.9,3.7$, and
4.65 wk pp (mean SED $=0.672 ; P=0.180)$ for the NP, EDP, and LP treatments, respectively.

When examined using repeated measures analysis, total DMI (Figure 1), BW (Figure 2), daily milk yield (Figure 3), and BCS (Figure 4) changed over the period from wk 1 to 19 postpartum $(P<0.001)$. We found no treatment $\times$ week interaction during this period for daily DMI, BW, or milk yield (all $P>0.1$ ), but there was an interaction between treatment and week postpartum for BCS $(P=0.004$; Figure 4$)$ such that NP cows lost body condition more slowly than did LP and EDP cows between wk 1 and 4 postpartum; those cows also failed to fully regain their BCS by wk 19 postpartum, unlike the LP and EDP cows.

When blood metabolites measured during wk 2, 4, 6, 8, and $10 \mathrm{pp}$ were examined using a repeated measures analysis, plasma glucose concentrations were higher $(P=0.002)$ in cows on the LP treatment, but mean serum BHB, fatty acid, and urea concentrations were unaffected (Figure 5). Concentrations of plasma glucose increased $(P<0.001)$ over the 10 -wk period postpartum, whereas serum fatty acids $(P<0.001)$, BHB $(P=0.001)$, and urea $(P=0.013)$ decreased over the 10 -wk measurement period. No treatment $\times$ week interactions were identified during this period $(P>0.1)$

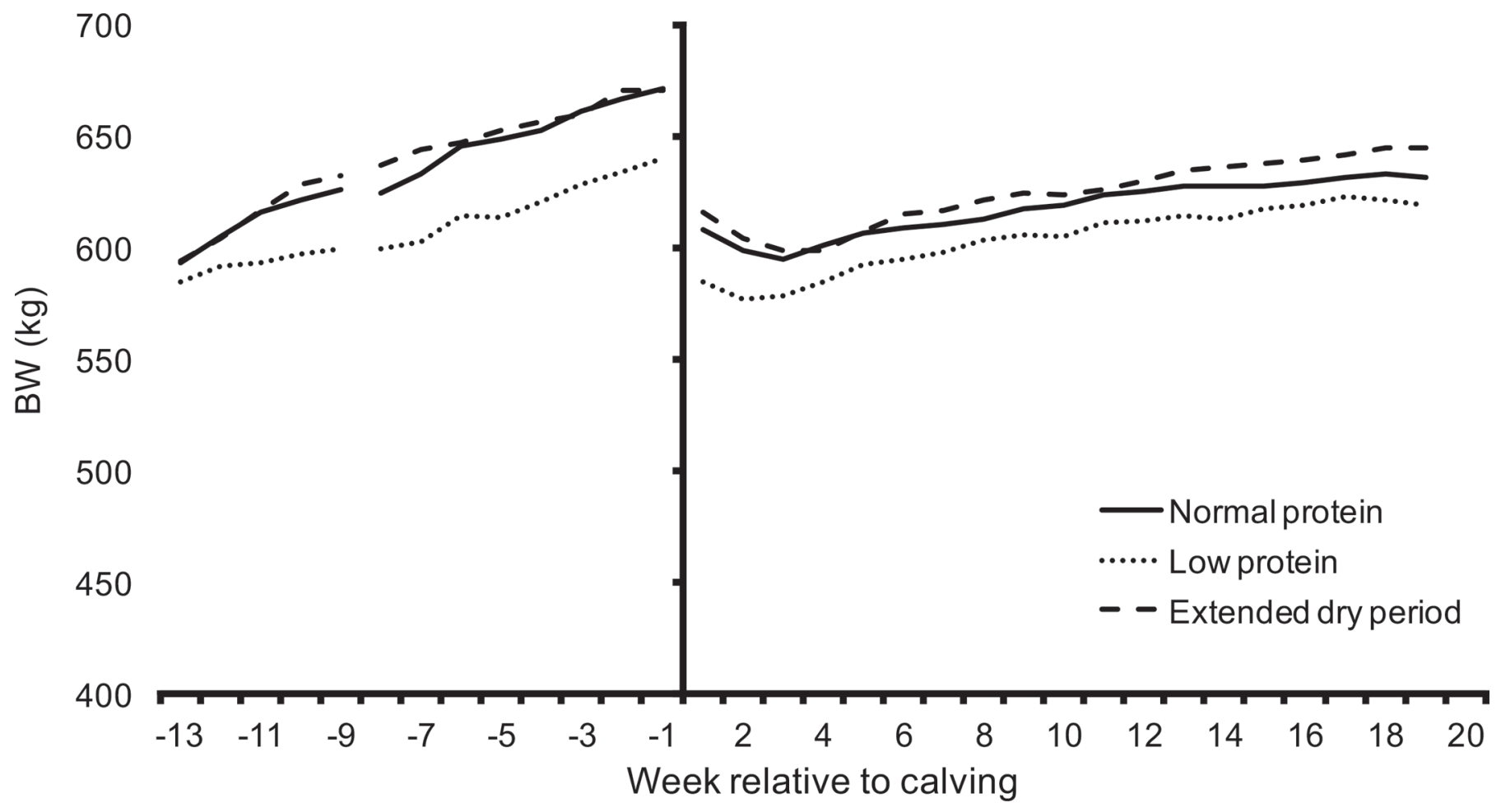

Figure 2. Effect of concentrate protein level in late lactation and dry period length on BW throughout the experiment. Main effects of treatment, week, and treatment $\times$ week interactions were noted; wk 13 to 9 prepartum: standard error of the difference (SED) $=7.19,2.04$, and $6.64, P$-value $=0.008,<0.001$, and 0.021, respectively; wk 8 to 1 prepartum: SED $=9.74,2.25$, and $8.46, P$-value $=0.001,<0.001$, and 0.042 , respectively; wk 1 to 19 postpartum: $\mathrm{SED}=9.82,2.84$, and $9.06, P$-value $=0.028,<0.001$, and 0.669 , respectively. 


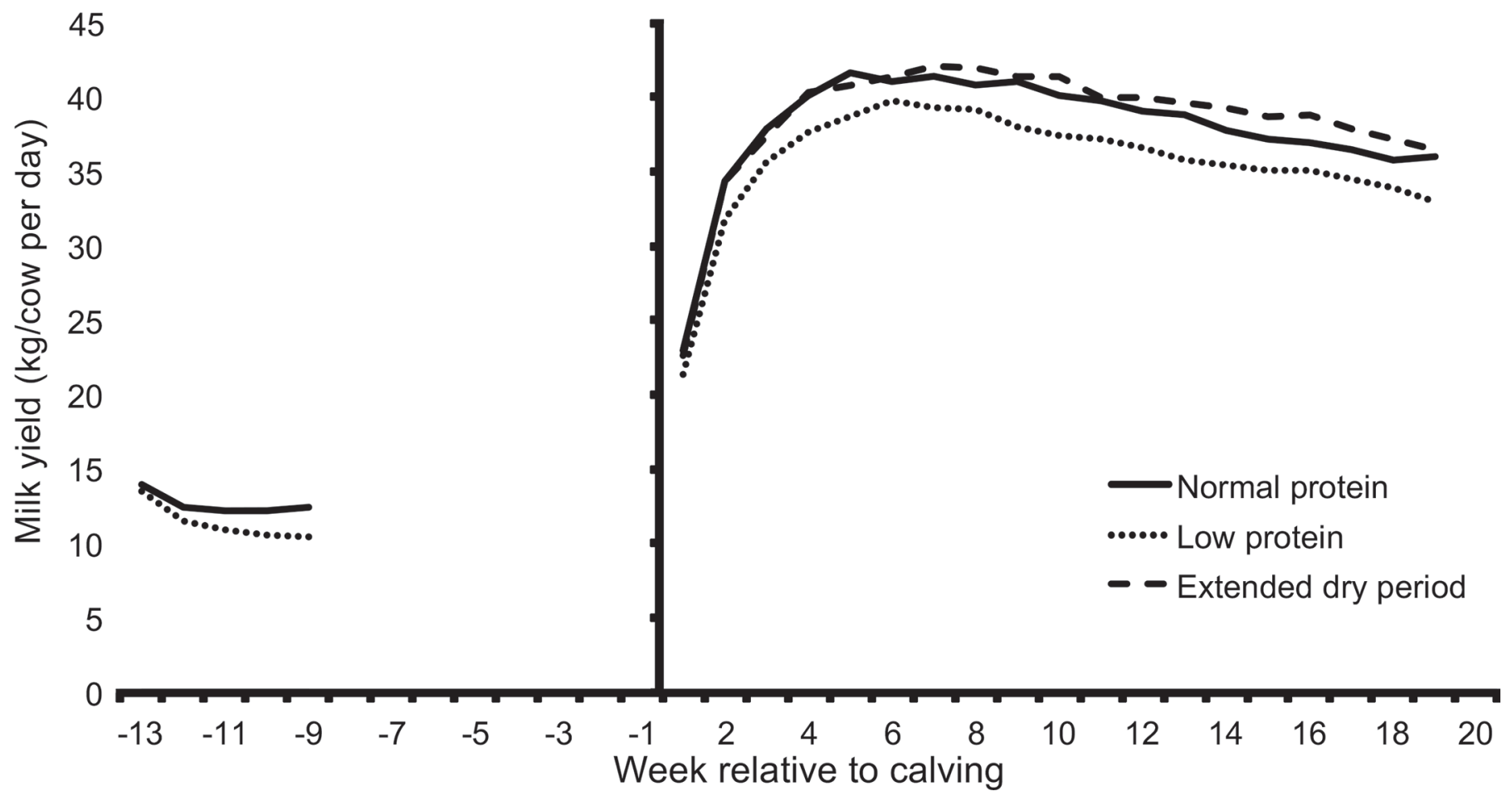

Figure 3. Effect of concentrate protein level in late lactation and dry period length on daily milk yield throughout the experiment. Main effects of treatment, week, and treatment $\times$ week interactions were noted; wk 13 to 9 prepartum: standard error of the difference $(\mathrm{SED})=0.68$, 0.25 , and $0.57, P$-value $=0.064,<0.001$, and 0.309 , respectively; wk 1 to 19 postpartum: $\mathrm{SED}=0.98,0.55$, and $1.23, P$-value $=0.010,<0.001$, and 0.358 , respectively.

for any of these metabolites. For serum haptoglobin concentrations measured during wk 2,4 , and 6 pp (Figure 6), we observed no treatment, week, or treatment $\times$ week interactions $(P>0.1)$.

Treatment did not affect $(P>0.1)$ any milk progesterone variable (Table 6 ) or pregnancy rate to first and second service $(P=0.665)$. Cows on the LP treatment tended to have a shorter calving interval $(P=0.072)$ than cows on either of the other 2 treatments, but treatment did not affect the prevalence of key fertility or health indicators during the first $19 \mathrm{wk}$ postpartum $(P>0.1)$. The proportion of cows treated for fertility problems was unaffected by treatment, as was the proportion of cows treated for mastitis, digestive upset, and lameness $(P>0.05)$.

\section{DISCUSSION}

The problems associated with thin dairy cows in early lactation are well documented. Improving the BCS of thin cows before calving is an important management goal on many dairy farms, but the optimum strategy by which this might be achieved is unclear. Our study investigated 2 approaches to improving the BCS of thin cows before calving, namely, the adoption of an extended dry period, and offering a diet with a lower protein and higher starch content in late lactation.

\section{Cow Performance from wk 13 to 8 Prepartum}

Studies with early- to mid-lactation cows have demonstrated that feed intake can be sustained provided dietary CP levels do not fall to excessively low levels, although milk yields are normally reduced with lowerprotein diets. For example, Cunningham et al. (1996) and Colmenero and Broderick (2006) found no difference in DMI between diets decreasing incrementally in $\mathrm{CP}$ content from 185 to 145 and from 194 to $135 \mathrm{~g} / \mathrm{kg}$ of DM, respectively, whereas FCM yields were reduced in these studies by $5.6(P=0.04)$ and by $2.5 \mathrm{~kg} / \mathrm{d}(P$ $=0.10)$, respectively. Law et al. (2009a) offered diets containing 114, 144, and $173 \mathrm{~g}$ of $\mathrm{CP} / \mathrm{kg}$ if $\mathrm{DM}$ to cows in early lactation and found DMI significantly reduced only on the lowest-protein diet, whereas milk yield differed significantly between all 3 diets. The concept of reducing diet protein level so as to reduce milk yield without a corresponding reduction in DMI, thereby improving EB in early lactation (d 1-150), was extended 
by Gilmore et al. (2011), who showed that even shortterm reductions in dietary $\mathrm{CP}$ content could be used to quickly improve the EB of dairy cows in early lactation.

Maintaining feed intake while reducing milk yield was a key premise of the LP treatment in the current study, with cows on this treatment expected to partition dietary energy not used for milk production to body tissue. The reduction in diet $\mathrm{CP}$ content from 158 to $137 \mathrm{~g} / \mathrm{kg}$ of DM for the NP and LP treatments, respectively, was sufficient to result in a significantly greater plasma urea concentration in cows on the NP treatment during wk 9 precalving. However, this reduction in diet CP content resulted in a $1.1-\mathrm{kg} / \mathrm{d}$ reduction in silage DMI and an associated late-lactation milk yield reduction of $1.2 \mathrm{~kg} / \mathrm{d}(12.6$ vs. $11.4 \mathrm{~kg} / \mathrm{d}$, respectively). Based on previous studies involving early-lactation cows, a reduction in diet $\mathrm{CP}$ content in excess of $20 \mathrm{~g} / \mathrm{kg}$ of DM was expected to result in a more substantial reduction in milk yield. For example, Ipharraguerre and Clark (2005) reviewed data from 112 trials involving dairy cows in early to mid lactation, with diets ranging from 121 to $258 \mathrm{~g}$ of $\mathrm{CP} / \mathrm{kg}$ of $\mathrm{DM}$; using their response curve, a difference of $2.2 \mathrm{~kg}$ of ilk/d was predicted between the NP and LP diets. Colmenero and Broderick (2006) reasoned that diets $\leq 160$ $\mathrm{g}$ of $\mathrm{CP} / \mathrm{kg}$ provide insufficient MP for maximal milk synthesis, making milk yield more sensitive to small changes in diet $\mathrm{CP}$ content at lower diet protein levels. Nevertheless, it is recognized that cows in late lactation are less responsive to changes in dietary protein level than are cows in early to mid lactation (Kalscheur et al., 1999), and those authors noted a reduction in DMI of $0.9 \mathrm{~kg} / \mathrm{cow}$ per day, with no effect on milk yield, when the CP content of late-lactation diets of similar RUP status was reduced from 142 to $125 \mathrm{~g} / \mathrm{kg}$ of DM. Law et al. (2009a) offered diets of 114, 144, and $173 \mathrm{~g}$ of $\mathrm{CP} / \mathrm{kg}$ of $\mathrm{DM}$ to Holstein-Friesian cows in later lactation (d 151-305) and found differences in DMI (16.8, 17.8 , and $19.3 \mathrm{~kg} / \mathrm{d}$, respectively; $P<0.05$ ) between all treatments, whereas milk yield was only significantly reduced with the lowest-protein diet (23.0 vs. 28.8 and $29.8 \mathrm{~kg} / \mathrm{d}$, respectively). These data highlight inconsistencies in late lactation responses to a reduction in dietary CP levels.

The reduction in late-lactation milk fat content in cows on the LP diet was consistent with the depressive effect of a low-protein diet on fiber digestibility (Faverdin, 1999), and is likely also to be associated with an impairment in ruminal acetate production. Both factors may have contributed to the unexpected reduction

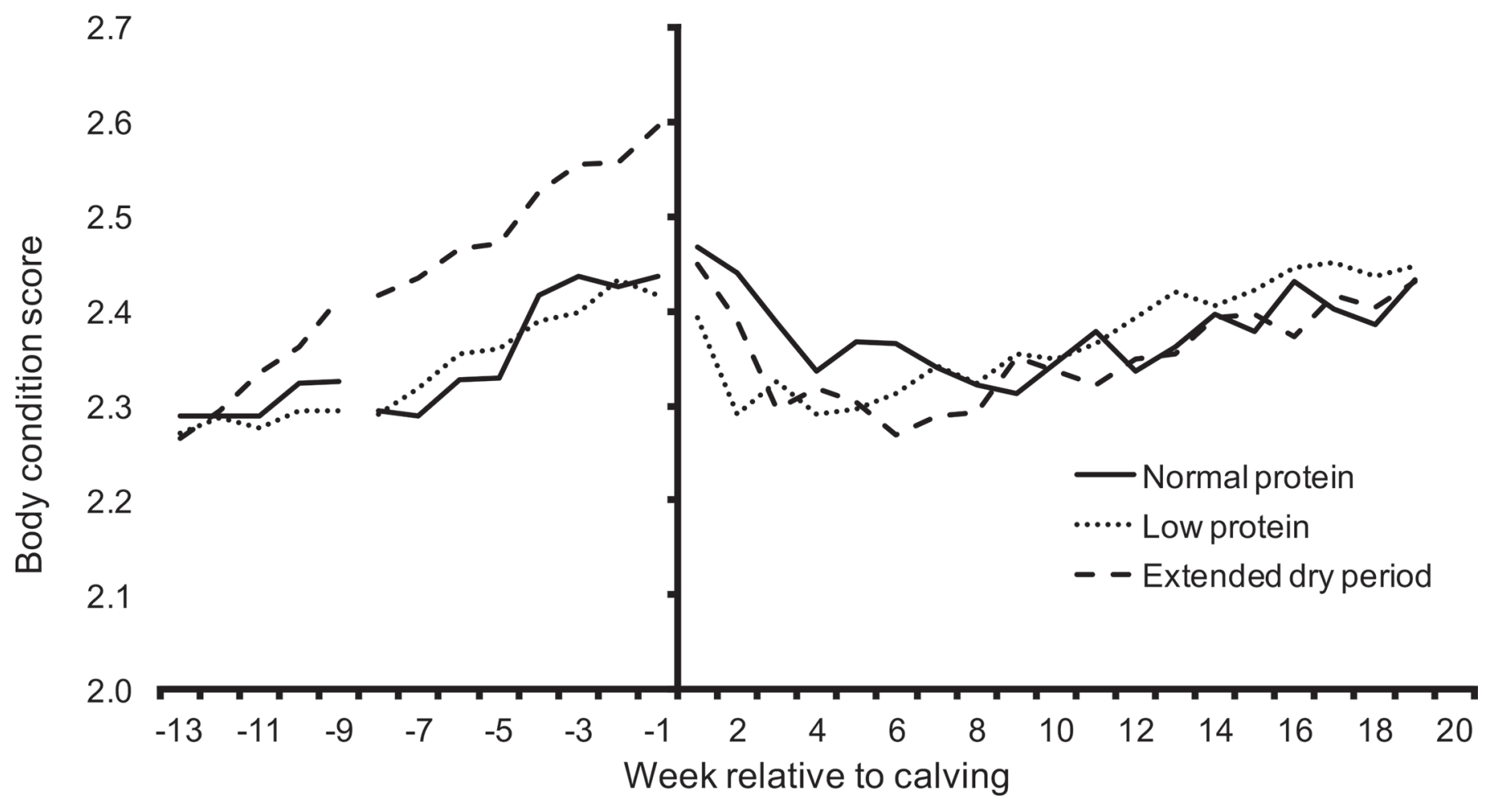

Figure 4. Effect of concentrate protein level in late lactation and dry period length on BCS throughout the experiment. Main effects of treatment, week, and treatment $\times$ week interactions were noted; wk 13 to 9 prepartum: standard error of the difference (SED) $=0.03$, 0.02, and $0.04, P$-value $=0.249,0.051$, and 0.491 , respectively; wk 8 to 1 prepartum: SED $=0.05,0.03$, and $0.06, P$-value $=0.002,<0.001$, and 0.923 , respectively; wk 1 to 19 postpartum: $\mathrm{SED}=0.05,0.04$, and $0.07, P$-value $=0.906,<0.001$, and 0.004 , respectively. 

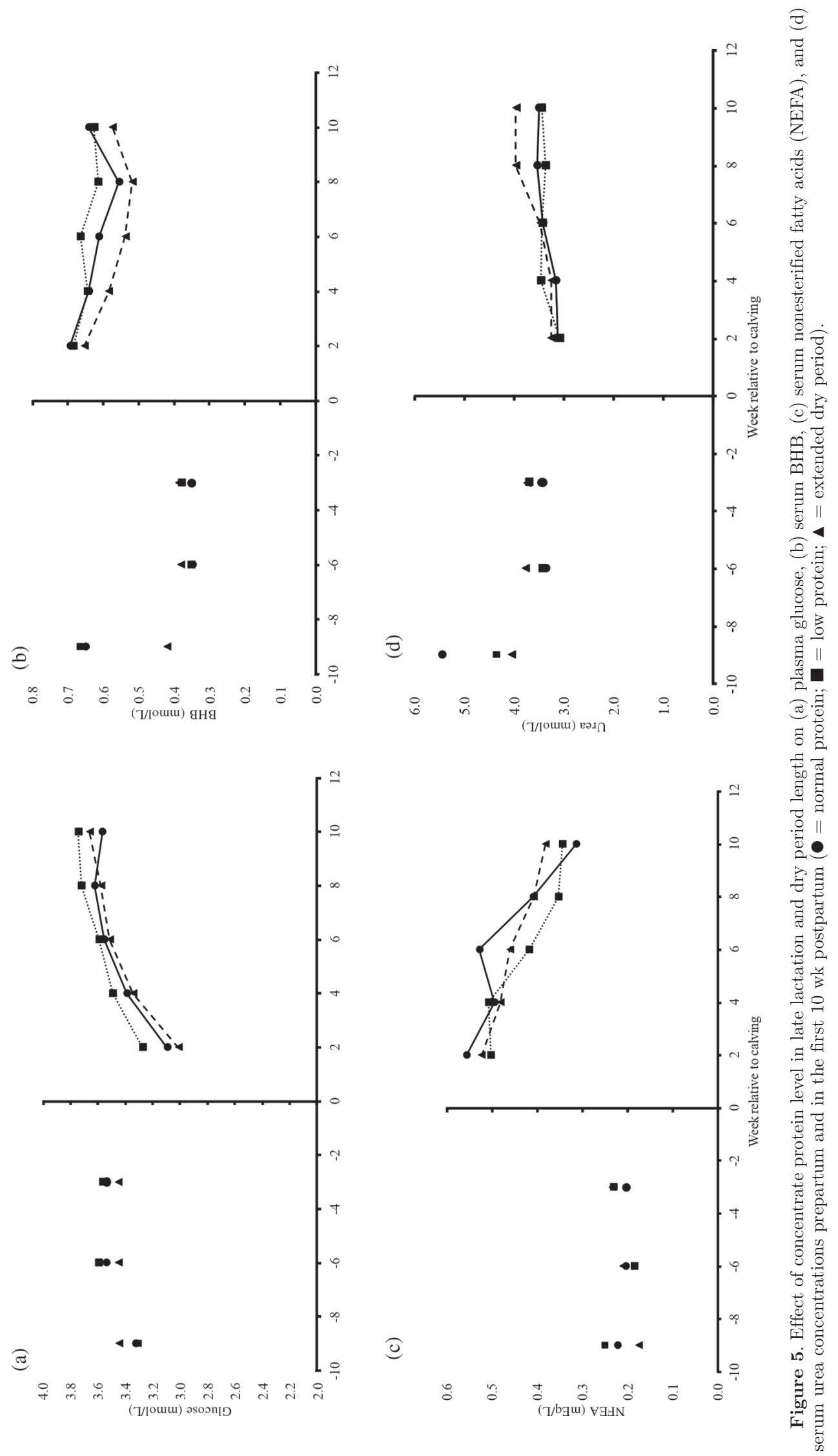

Journal of Dairy Science Vol. 100 No. 3, 2017 
Table 4. Effect of concentrate protein level in late lactation and dry period length on silage intake, BW, and BCS from 8 to 1 wk prepartum

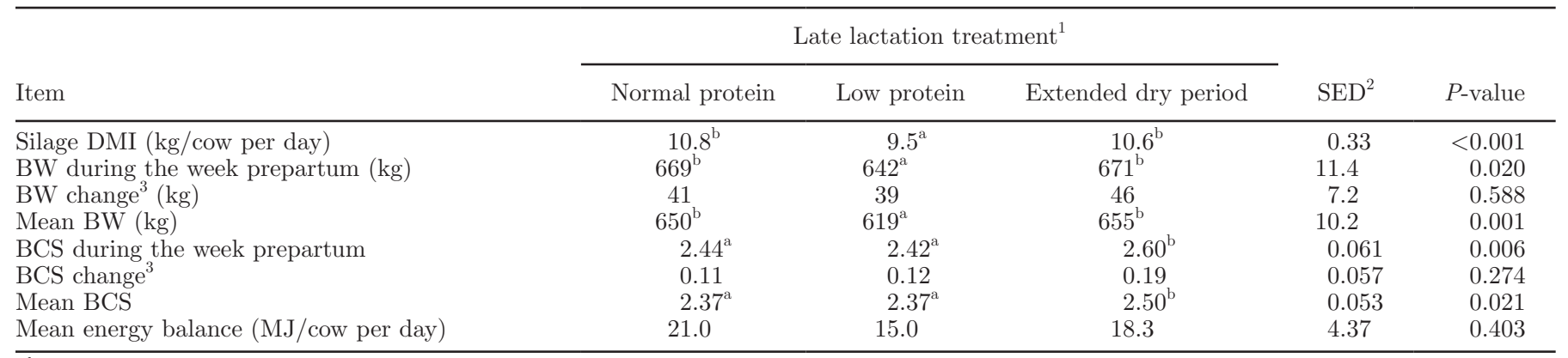

${ }^{\mathrm{a}, \mathrm{b}}$ Means with different superscripts within rows differ $(P<0.05)$.

${ }^{1}$ Treatments imposed over a 5 -wk period, commencing 13 wk prepartum.

${ }^{2}$ Standard error of the difference.

${ }^{3}$ Difference between wk 8 and 1 prepartum.

in DMI, with this compounded by the higher levels of starch in this diet.

Energy balance data for the 5 -wk period before drying off showed no significant difference between the NP and LP treatments and is supported by the absence of differences in BCS responses, as well as in plasma glucose, fatty acid, and BHB concentrations between cows on these 2 treatments. However, cows on the NP treatment showed an unexpectedly large increase in BW during the period from wk 13 to 9 prepartum compared with those on the LP diet (56 vs. $29 \mathrm{~kg}$, respectively). Differential rumen-fill effects may have been a factor in this, as forage DMI during this period was lower for the LP diet. Rumen volume is affected by forage NDF content (Van Soest, 1994); whereas the NP and LP diets had similar NDF contents, the 1.1 $\mathrm{kg} / \mathrm{d}$ difference in silage DMI between the NP and LP diets equates to a difference of almost $600 \mathrm{~g}$ of NDF/d between NP and LP cows. Nevertheless, in summary, offering a lower-protein, higher-starch diet in late lactation did not improve BCS in late lactation, contrary to expectations.

By definition, cows on the EDP treatment produced no milk during the period from wk 13 to 9 prepartum, resulting in a reduction in milk yield during this lactation of approximately $380 \mathrm{~kg}$ (compared with cows

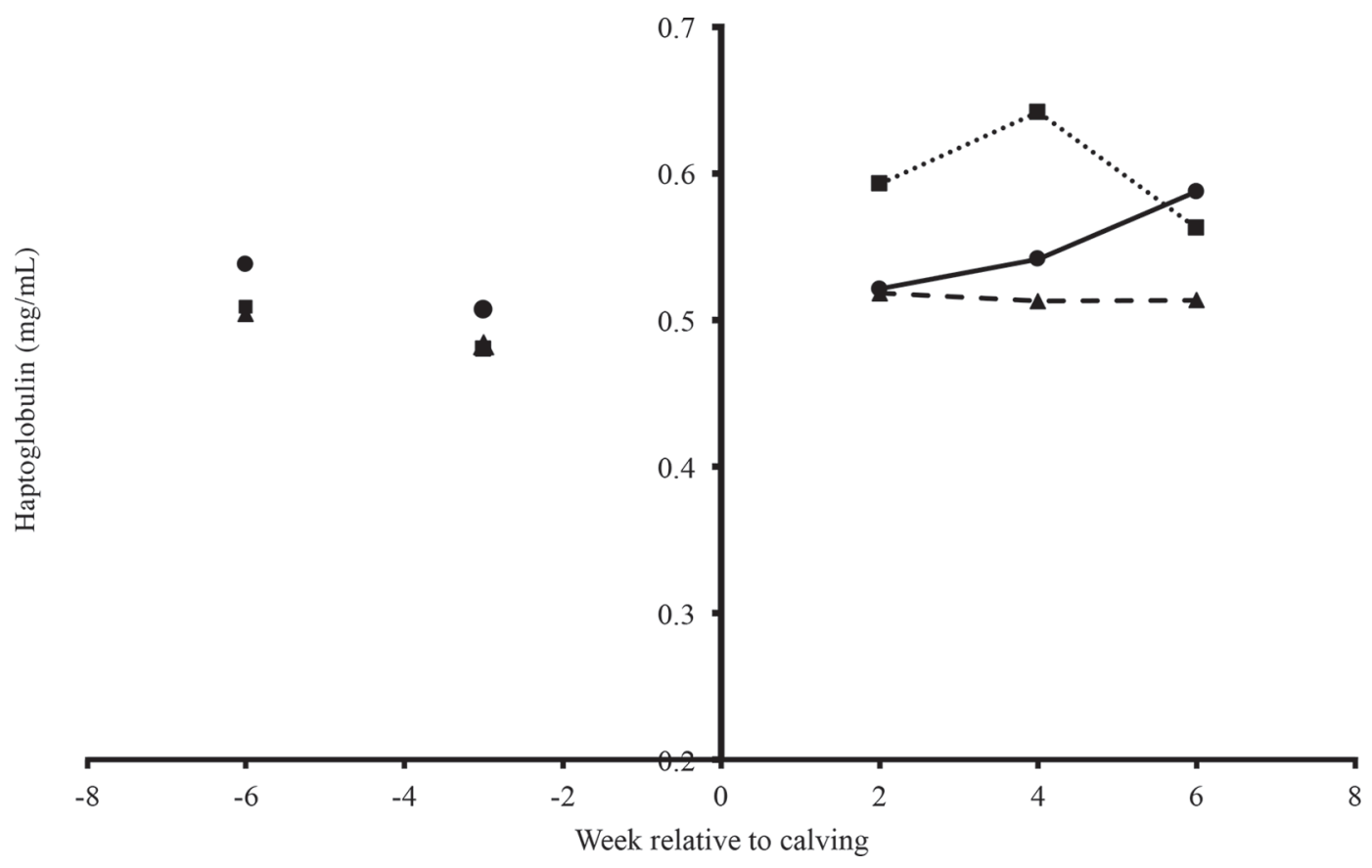

Figure 6. Effect of concentrate protein level in late lactation and dry period length on serum haptoglobin concentrations prepartum and at wk 2 , 4, and 6 postpartum $(\bullet=$ normal protein; $\mathbf{\square}=$ low protein; $\boldsymbol{\Lambda}=$ extended dry period $)$. 
Table 5. Effect of concentrate protein level in late lactation and dry period length on food intake, milk yield, milk composition, BW, and BCS during the first 19 wk of lactation

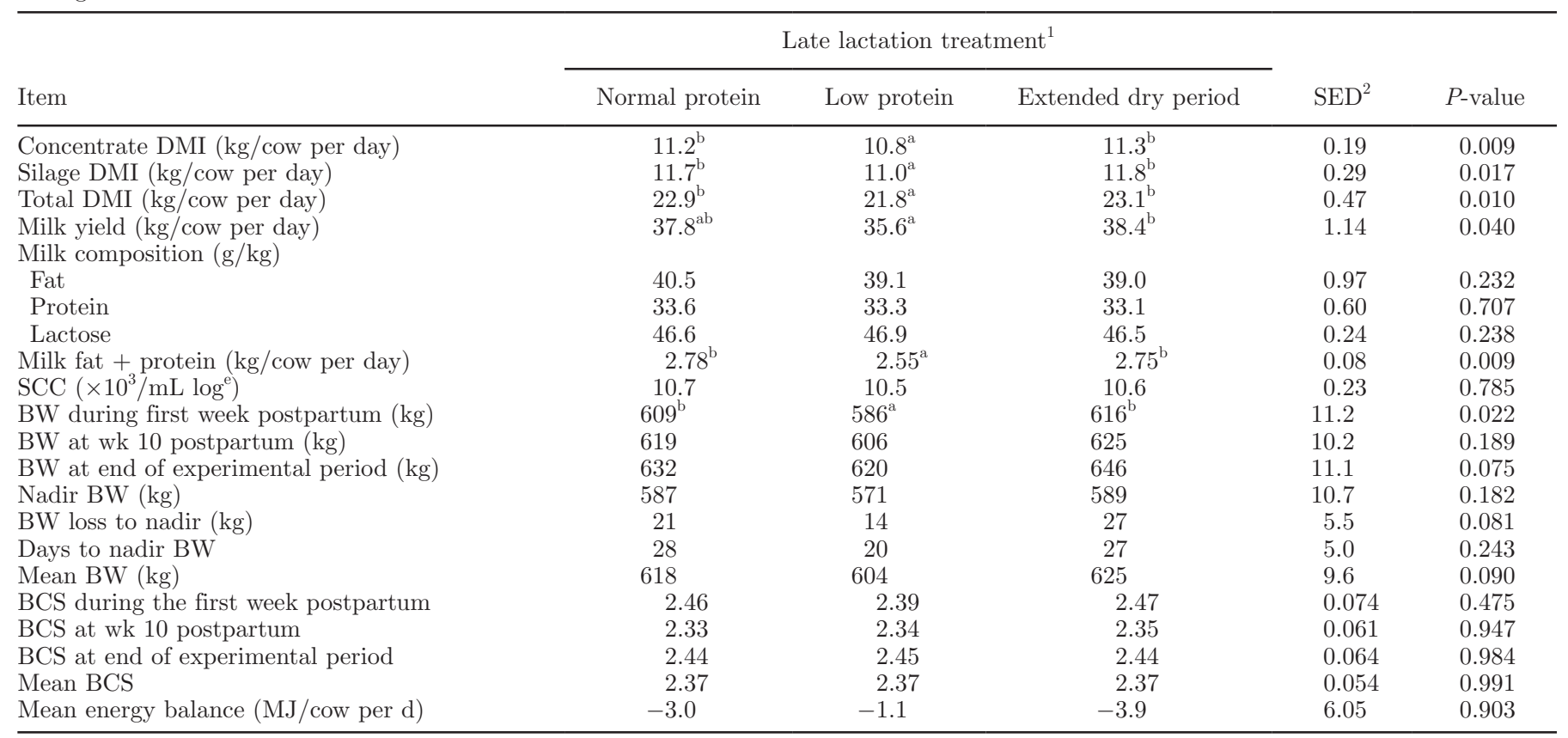

${ }^{\mathrm{a}, \mathrm{b}}$ Means with different superscripts within rows differ $(P<0.05)$.

${ }^{1}$ Treatments imposed over a 5 -wk period, commencing at 13 wk prepartum.

${ }^{2}$ Standard error of the difference

on the NP and LP treatments). The loss in milk was associated with a saving in concentrates of $175 \mathrm{~kg} / \mathrm{cow}$, whereas forage DMI was similar to that of cows on the NP treatment. Thus the immediate economic effect of an extended DP will be determined by current milk price-to-concentrate cost ratios.
The calculated EB values for this period highlight that EDP cows tended to have an improved energy status relative to cows on the LP treatment $(P=$ 0.098), although not being different from cows on the NP treatment, with this largely reflected in the lower serum BHB and fatty acid concentrations with EDP at

Table 6. Effect of concentrate protein level in late lactation and dry period length on cow health and fertility during the first 19 wk of lactation

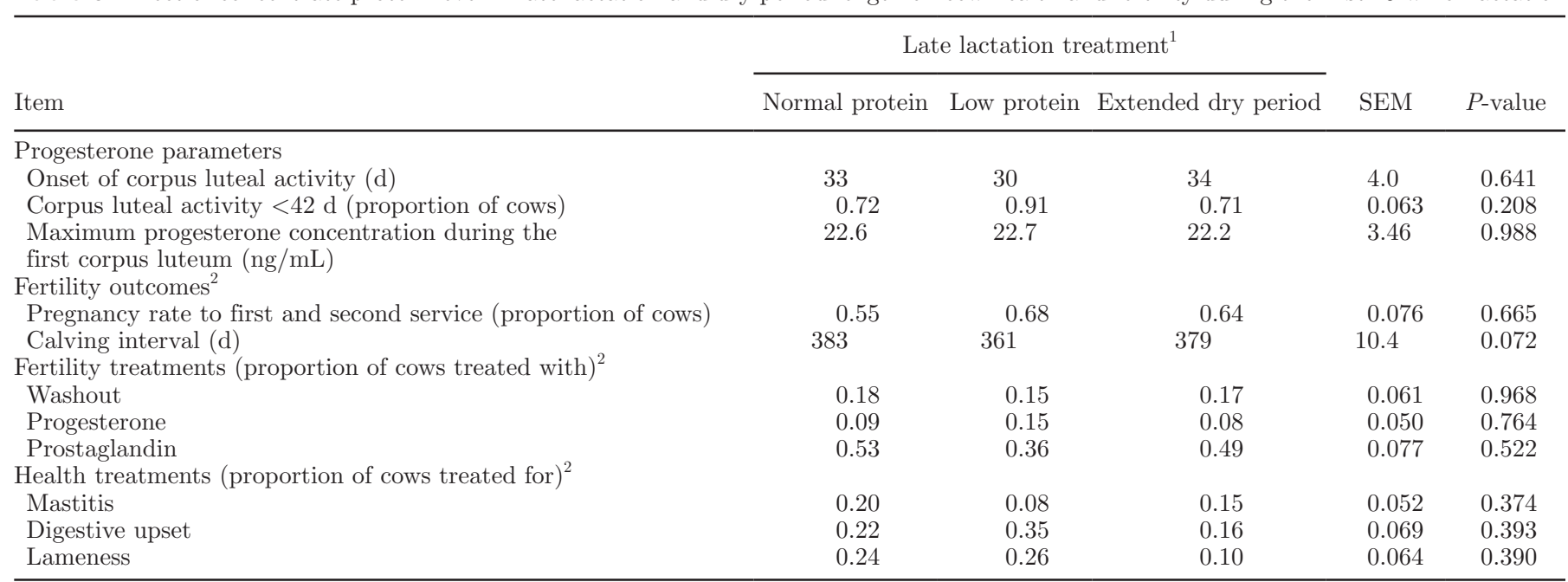

${ }^{1}$ Treatments imposed over a 5 -wk period, commencing at 13 wk prepartum.

${ }^{2}$ Performance monitored over a 19 -wk period postpartum. 
9 wk prepartum. Although we found a trend for cows on the EDP treatment to gain more BCS than cows on either of the other 2 treatments, no treatment $\times$ time interaction was noted for BCS gain; thus, cows managed on the EDP treatment had similar BCS gain to those on the NP treatment, perhaps reflecting the short duration of the observation period.

\section{Cow Performance from wk 8 Precalving Until Calving}

Whereas cows on all treatments were offered a common diet from wk 8 prepartum until calving, cows on the LP diet continued to have a lower forage intake than either NP or EDP cows. The reasons for this carry-over effect are unclear, as it would have been expected that any negative effects on rumen function would have been short-lived after these cows moved on to a common diet. Although the BW of cows on the LP treatment remained lower than that of cows on the other 2 treatments throughout the precalving period, BW gain was similar across all treatments. Weight gain in cows at this stage of gestation largely reflects exponential fetal growth rather than maternal weight gain, consistent with the modest increases in BCS across all treatments during this 8 -wk period (range $=0.11-0.19$ units). These relatively small gains are consistent with the outcomes of previous studies at this institute (Law et al., 2016; Little et al., 2016b), which showed that cows offered moderate quality grass silage-based diets, either supplemented or not, gain little body condition during the 8-wk period precalving, reflecting the move toward NEB during the last few weeks before calving.

A paucity of published data exist on the effects of adopting a dry period of more than 56 to $60 \mathrm{~d}$ on BCS and BW at calving, reflecting the reluctance to adopt longer DP, as they are considered prejudicial to lifetime productivity (Kuhn et al., 2006). However, it is unclear if this holds true for thin cows, as their increased risk of being culled during the subsequent lactation (Law et al., 2016) is clearly also prejudicial to lifetime performance. Cows on the EDP treatment ended the 8-wk precalving period with a significantly higher BCS than cows on the other 2 treatments, having gained approximately 0.4 BCS units during the 13 wk before calving. Thus, the adoption of an extended DP allowed the thin cows in the current study to gain more body condition than was possible with a conventional 8-wk DP and move closer to a precalving BCS of 2.75 , regarded as optimal by Garnsworthy (2007). The between-treatment similarity of plasma glucose and serum BHB, fatty acid, and urea concentrations at 6 and $3 \mathrm{wk}$ precalving suggested a similar metabolic status of cows across all treatments at this time, in agreement with the calculated $\mathrm{EB}$ data.

\section{Cow Performance During wk 1 to 19 Postpartum}

Whereas all cows were managed on a common diet postcalving, cows on the LP treatment continued to have a significantly lower DMI than cows on the NP treatment over the first 19 wk of lactation, similar to the 8 -wk period prepartum. We found no obvious explanation for this long-term carry over effect, other than that these cows were lighter in BW at calving, again a carry-over from the prepartum period. Whereas neither mean milk yield nor mean milk fat or protein content differed between treatments NP and LP over the 19-wk period, both were numerically lower with the LP treatment so that milk fat and protein yield was significantly lower with the LP treatment, in line with the lower DMI with this treatment. The combined effects of a lower DMI and lower fat plus protein yield with the LP treatment was that mean EB was unaffected by treatment. This was reflected in the absence of a treatment effect on BCS or on serum BHB and fatty acid concentrations during the postcalving period.

Evidence relating to the effects of an extended DP on dairy cow performance is inconsistent. For example, Weglarzy (2009) found that cows that had DP from 61 to $90 \mathrm{~d}$ had $12.6 \%$ greater 305 -d milk yields in the subsequent lactation than cows given a DP $<60$ or $>90$ d. In contrast, Kuhn et al. (2006) analyzed 7 yr of US DHIA data and concluded that a DP $>60$ d was associated with lower milk production in the next lactation and, often, a loss of lifetime milk production; also, cows receiving a $\mathrm{DP} \geq 90$ d typically yielding $>4,000 \mathrm{~kg}$ less lifetime milk than those on a 40 to $60 \mathrm{~d}$ DP. Yield losses were substantial even in cows that received a 70 to $90 \mathrm{~d} \mathrm{DP}$; however, both of these retrospective studies included data from cows with DP that differed naturally in length as a consequence of reactive management decisions rather than as a prearranged consequence of experimental design, as was the case in the current study. Similarly, Weber et al. (2015) compared the effects of a 28-, 56-, and 90-d DP for dairy cows and found that neither total milk production nor milk composition over the first $200 \mathrm{~d}$ of lactation differed between cows given a $90-\mathrm{d} \mathrm{DP}$ and those given a $56-\mathrm{d}$ DP. However, whereas cows on the 28- and 56-d DP in the Weber et al. (2015) study were randomly selected from a common pool, cows given the extended 90-d DP were dried off earlier because, and when, their milk yield had declined to $\leq 15 \mathrm{~kg} / \mathrm{d}$. In one of the few studies to have imposed preplanned dry periods of variable length on dairy cows, Sørensen and Enevoldsen (1991) assessed the effect of DP of 4,7 , and 10 wk on subsequent lactation yields across 8 herds $(\mathrm{n}=366$ cows) and found that a 10-wk DP resulted in an increase of 
$0.5 \mathrm{~kg} / \mathrm{d}$ of $4 \% \mathrm{FCM}$ up to $\mathrm{d} 84$ of lactation, and 0.4 $\mathrm{kg} / \mathrm{d}$ up to $\mathrm{d} 184$ of lactation. However, in the current study, neither the DMI nor milk yield of cows allocated to the extended DP treatment differed from those of cows on the NP treatment.

A significant risk associated with the imposition of an extended DP is that cows may become overly fat. Garnsworthy (2007) and Drackley and Cardoso (2014) advised that cows given a greatly extended DP should be managed individually to avoid over-conditioning, as it is well known that cows with a higher BCS at calving lose more BCS early postpartum (Garnsworthy and Topps, 1982; Bjerre-Harpøth et al., 2014). Lower pre- and postcalving DMI (Roche et al., 2013) impaired immune function (Lange et al., 2016), and poorer reproductive performance (Garnsworthy et al., 2008; Hoedemaker et al., 2009) are all associated with cows that mobilize more fat postpartum. In the current study, cows on the EDP treatment had a higher BCS at calving than those on the NP treatment (2.60 vs. 2.44), but all cows in the study remained demonstrably thin at drying off and were at no risk of becoming excessively fat on the grass silage diets offered to them during the dry period. As in the study of Weber et al. (2015), the advantage of a higher BCS at calving in cows on the EDP treatment was quickly lost postpartum. Indeed, the BCS of all cows began to merge shortly after calving and did not differ at 19 wk into lactation. Cows that are nutritionally manipulated to make them either fatter or leaner at calving experience a change in the rate of BCS loss post-calving that helps re-establish normal body fatness levels by 3 to 4 mo pp (Friggens, 2003; Garnsworthy, 2007; Law et al., 2011b). In the current study, extending the DP gave no longer-term performance benefits despite clearly allowing significantly greater BCS gains before calving than in cows with a conventional DP.

\section{Cow Reproductive Performance and Cow Health}

The effect of low-CP diets and lower-CP intakes on dairy cow fertility has not been thoroughly investigated. Law et al. (2009b,c) found several measures of fertility performance were unaffected by dietary $\mathrm{CP}$ content in early lactation, even though a higher diet $\mathrm{CP}$ content reduced the average daily $\mathrm{EB}$ of the cows. However, the effect of offering a low-CP diet in late lactation on fertility performance during the subsequent lactation does not appear to have been examined previously. Similarly, the effect of extending the DP on fertility performance has not been extensively investigated through planned experiments. Pinedo et al. (2011) retrospectively examined the association between DP lengths ranging from 0 to $250 \mathrm{~d}$ on a variety of cow performance parameters (including reproductive performance) in Chilean dairy herds and found only that extending the DP beyond 143 $\mathrm{d}$ had a negative effect on reproductive performance in the subsequent lactation.

Milk progesterone measurements in the current study provided no evidence that cyclicity onset was influenced either by offering a low-CP diet in late lactation or by extending the length of the DP. Nevertheless, cows with a lower BCS at calving are more likely to have a longer calving interval. Pryce et al. (2001) and Roche et al. (2007) found difficulty rebreeding thin dairy cows within an acceptable period, probably due to the recognized delay in the resumption of ovarian luteal activity in thinner cows (Markusfeld et al., 1997; Reksen et al., 2002). The current study did not involve a normal BCS group, but cows on the EDP treatment gained more body condition during their extended dry period and had a higher BCS at calving than those on either of the other 2 treatments. Nevertheless, the key metric of conception rates to first and second service was unaffected by treatment, although the number of cows involved was inadequate to robustly assess fertility outcomes.

Thin cows have reduced immune competence and an associated increased disease incidence (Hoedemaker et al., 2009) and are more likely to be culled during early lactation than cows with a higher BCS (Law et al., 2016). However, treatment had no effect on immune status prepartum or postpartum, as assessed by serum haptoglobin levels in the current study. Increases in serum haptoglobin level occur in response to inflammatory stimuli and are exacerbated by mastitis, lameness, metritis, and metabolic stress (Little et al., 2016a). Whereas haptoglobin provides only one assessment of immune function, cow health (incidence of cows requiring uterine washouts, mastitis, lameness, and digestive upset) was unaffected by treatment in our study despite an improved BCS at calving for cows on the EDP treatment; this supports the fertility data above. For example, the incidence of uterine infection is a key driver of fertility outcomes (Walsh et al., 2011; Little et al., 2016b), with Hoedemaker et al. (2009) observing that thin $(\mathrm{BCS}<3)$ cows were at greater risk of dystocia, retained placenta, and endometritis than cows in better condition (BCS $\geq, 3$ ). The proportion of cows treated for uterine washouts did not differ in the current study. In a recent study, Roche et al. (2015) concluded that thin cows should be fed to their prescribed requirements to maintain or improve their immunity, with mean energy requirements during the dry period met by all treatments in the current study, as demonstrated by the EB data. Overall, we found no discernible benefit of either a low-protein diet (LP) or an extended dry period (EDP) on the health and fertility of the thin cows in this study. 


\section{CONCLUSIONS}

Offering a lower-protein, higher-starch diet to thin cows in late lactation reduced DMI and milk fat plus protein yield, but had no effect on BCS at calving. The lower feed intakes persisted throughout the subsequent lactation, whereas we found no beneficial effects on cow fertility or health. Although the adoption of an extended dry period resulted in an improved BCS at calving compared with cows offered a normal protein diet, this difference was small and disappeared after calving. The extended dry period had no beneficial effects on cow performance, health, or fertility during the subsequent lactation.

\section{ACKNOWLEDGMENTS}

This work was part of DAERA Research Challenge Fund Project RCF 05/2014, funded jointly by DAERA (the Department of Agriculture, Environment and Rural Affairs; a department within the Northern Ireland Executive, Dundonald, Belfast, UK) and Agrisearch (Dungannon, Co. Tyrone, UK; commissioning body for farmer funded production-orientated research within Northern Ireland).

\section{REFERENCES}

Bjerre-Harpøth, V., M. Larsen, N. C. Friggens, T. Larsen, M. R. Weisbjerg, and B. M. Damgaard. 2014. Effect of dietary energy supply to dry Holstein cows with high or low body condition score at dry off on production and metabolism in early lactation. Livest. Sci. 168:60-75

Borsberry, S., and H. Dobson. 1989. Periparturient diseases and their effect on reproductive performance in five dairy herds. Vet. Rec. 124:217-219.

Chilliard, Y., A. Ferlay, Y. Faulconnier, M. Bonnet, J. Rouel, and F. Bocquier. 2000. Adipose tissue metabolism and its role in adaptations to undernutrition in ruminants. Proc. Nutr. Soc. 59:127-134.

Colmenero, J. J., and G. A. Broderick. 2006. Effect of dietary crude protein concentration on milk production and nitrogen utilization in lactating dairy cows. J. Dairy Sci. 89:1704-1712.

Cunningham, K. D., M. J. Cecava, T. R. Johnson, and P. A. Ludden 1996. Influence of source and amount of dietary protein on milk yield by cows in early lactation. J. Dairy Sci. 79:620-630.

Drackley, J. K., and F. C. Cardoso. 2014. Prepartum and postpartum nutritional management to optimize fertility in high-yielding dairy cows in confined TMR systems. Animal 8:5-14.

Edmondson, A. J., I. J. Lean, L. D. Weaver, T. Farver, and G. Webster. 1989. A body condition scoring chart for Holstein dairy cows. J. Dairy Sci. 72:68-78.

Faverdin, P. 1999. The effect of nutrients on feed intake in ruminants. Proc. Nutr. Soc. 58:523-531.

Ferris, C. P., and C. S. Mayne. 2003. The response to concentrate supplementation of dairy cows grazing late summer/autumn grass. Page 127 in Proc. British Soc. Anim. Sci. Ann. Conf., York, UK. BSAS, Edinburgh, UK

Friggens, N. C. 2003. Body lipid reserves and the reproductive cycle: Towards a better understanding. Livest. Prod. Sci. 83:219-236.

Garnsworthy, P. C. 2007. Body condition score in dairy cows: targets for production and fertility. Pages $61-86$ in Recent Advances in Animal Nutrition - 2006. P. C. Garnsworthy and J. Wiseman, ed. Nottingham University Press, Nottingham, UK.
Garnsworthy, P. C., K. D. Sinclair, and R. Webb. 2008. Integration of physiological mechanisms that influence fertility in dairy cows. Animal 2:1144-1152.

Garnsworthy, P. C., and J. H. Topps. 1982. The effect of body condition of dairy cows at calving on their food intake and performance when given complete diets. Anim. Prod. 35:113-119.

Gilmore, H. S., F. J. Young, D. C. Patterson, A. R. G. Wylie, R. A Law, D. J. Kilpatrick, C. T. Elliott, and C. S. Mayne. 2011. An evaluation of the effect of altering nutrition and nutritional strategies in early lactation on reproductive performance and estrous behavior of high-yielding Holstein-Friesian dairy cows. J. Dairy Sci. 94:3510-3526.

Heuer, C., Y. H. Schukken, and P. Dobbelaar. 1999. Postpartum body condition score and results from the first test day milk as predictors of disease, fertility, yield, and culling in commercial dairy herds. J. Dairy Sci. 82:295-304.

Hoedemaker, M., D. Prange, and Y. Gundelach. 2009. Body condition change ante- and postpartum, health and reproductive performance in German Holstein cows. Reprod. Domest. Anim. 44:167173.

Ipharraguerre, I. R., and J. H. Clark. 2005. Impacts of the source and amount of crude protein on the intestinal supply of nitrogen fractions and performance of dairy cows. J. Dairy Sci. 88:E22-E37.

Kalscheur, K. F., J. H. Vandersall, R. A. Erdman, R. A. Kohn, and E. Russek-Cohen. 1999. Effects of dietary crude protein concentration and degradability on milk production responses of early, mid, and late lactation dairy cows. J. Dairy Sci. 82:545-554.

Kuhn, M. T., J. L. Hutchison, and H. D. Norman. 2006. Dry period length to maximize production across adjacent lactations and lifetime production. J. Dairy Sci. 89:1713-1722.

Lange, J., A. McCarthy, J. Kay, S. Meier, C. Walker, M. A. Crookenden, M. D. Mitchell, J. J. Loor, J. R. Roche, and A. Heiser. 2016. Prepartum feeding level and body condition score affect immunological performance in grazing dairy cows during the transition period. J. Dairy Sci. 99:2329-2338

Law, R. A., S. McGettrick, and C. P. Ferris. 2011a. Effect of concentrate build-up strategy in early lactation on production performance, health and fertility of high yielding dairy cows. Page 5 in Proc. British Soc. Anim. Sci. Ann. Conf., Nottingham, UK. BSAS, Edinburgh, UK.

Law, R. A., M. Romero Oiartzun, A. Brown, A. Gordon, A. F. Carson, and C. P. Ferris. 2016. The effects of offering concentrates during the dry period on dairy cow performance. Page 371 in Proc. Eur. Assoc. Anim. Prod. Conf. Belfast, UK. European Association for Animal Production, Rome, Italy.

Law, R. A., F. J. Young, D. C. Patterson, D. J. Kilpatrick, A. R G. Wylie, K. L. Ingvarsten, A. Hameleers, M. A. McCoy, C. S. Mayne, and C. P. Ferris. 2011b. Effect of precalving and postcalving dietary energy level on performance and blood metabolite concentrations of dairy cows throughout lactation. J. Dairy Sci. $94: 808-823$.

Law, R. A., F. J. Young, D. C. Patterson, D. J. Kilpatrick, A. R. G. Wylie, and C. S. Mayne. 2009a. Effect of dietary protein content on animal production and blood metabolites of dairy cows during lactation. J. Dairy Sci. 92:1001-1012.

Law, R. A., F. J. Young, D. C. Patterson, D. J. Kilpatrick, A. R. G. Wylie, and C. S. Mayne. 2009b. Effect of dietary protein content on the fertility of dairy cows during early and mid lactation. J. Dairy Sci. 92:2737-2746.

Law, R. A., F. J. Young, D. C. Patterson, D. J. Kilpatrick, A. R. G. Wylie, and C. S. Mayne. 2009c. Effect of dietary protein content on estrous behavior of dairy cows during early and mid lactation. J. Dairy Sci. 92:1013-1022.

Little, M. W., N. E. O'Connell, and C. P. Ferris. 2016a. A comparison of individual cow versus group concentrate allocation strategies on dry matter intake, milk production, tissue changes, and fertility of Holstein-Friesian cows offered a grass silage diet. J. Dairy Sci. 99:4360-4373.

Little, M. W., N. E. O'Connell, M. D. Welsh, J. Barley, K. G. Meade, and C. P. Ferris. 2016b. Prepartum concentrate supplementation of a medium quality grass silage based diet: Effects on perfor- 
mance, health, fertility, metabolic function and immune function of low body condition score cows. J. Dairy Sci. 99:7102-7122.

Little, M. W., N. E. O'Connell, M. D. Welsh, F. J. Mulligan, and C. P. Ferris. 2017. Concentrate supplementation of a medium quality grass silage-based diet for 4 weeks prepartum: Effects on cow performance, health, metabolic status, and immune function. J. Dairy Sci. https://doi.org/10.3168/jds.2016-11806.

Markusfeld, O., N. Galon, and E. Ezra. 1997. Body condition score, health, yield and fertility in dairy cows. Vet. Rec. 141:67-72.

Park, R. S., R. E. Agnew, F. J. Gordon, and R. W. J. Steen. 1998. The use of near infrared reflectance spectroscopy (NIRS) on undried samples of grass silage to predict chemical composition and digestibility parameters. Anim. Feed Sci. Technol. 72:155-167.

Payne, R. W., S. A. Harding, D. A. Murray, D. M. Soutar, D. B. Baird, A. I. Glaser, I. C. Channing, S. J. Welham, A. R. Gilmour, R. Thompson, and R. Webster. 2013. The Guide to GenStat Release 16, Part 2: Statistics. VSN International, Hemel Hempstead, UK.

Pinedo, P., C. Risco, and P. Melendez. 2011. A retrospective study on the association between different lengths of the dry period and subclinical mastitis, milk yield, reproductive performance, and culling in Chilean dairy cows. J. Dairy Sci. 94:106-115.

Pryce, J. E., M. P. Coffey, and S. Brotherstone. 2000. The genetic relationship between calving interval, body condition score and linear type and management traits in registered Holsteins. J. Dairy Sci. 83:2664-2671.

Pryce, J. E., M. P. Coffey, and G. Simm. 2001. The relationship between body condition score and reproductive performance. J. Dairy Sci. 84:1508-1515.

Purcell, P. J., R. A. Law, A. W. Gordon, S. A. McGettrick, and C. P. Ferris. 2016. Effect of concentrate feeding method on the performance of dairy cows in early to mid lactation. J. Dairy Sci. 99:2811-2824.

Reksen, O., Ø. Havrevoll, Y. T. Grohn, T. Bolstad, A. Waldmann, and E. Ropstad. 2002. Relationships among body condition score, milk constituents, and postpartum luteal function in Norwegian dairy cows. J. Dairy Sci. 85:1406-1415.
Roche, J. R., A. W. Bell, T. R. Overton, and J. J. Loor. 2013. Nutritional management of the transition cow in the 21st century- $\mathrm{A}$ paradigm shift in thinking. Anim. Prod. Sci. 53:1000-1023.

Roche, J. R., N. C. Friggens, J. K. Kay, M. W. Fisher, K. J. Stafford, and D. P. Berry. 2009. Invited review: Body condition score and its association with dairy cow productivity, health, and welfare. J. Dairy Sci. 92:5769-5801.

Roche, J. R., K. A. Macdonald, C. R. Burke, J. M. Lee, and D. P. Berry. 2007. Associations among body condition score, body weight, and reproductive performance in seasonal-calving dairy cattle. J. Dairy Sci. 90:376-391.

Roche, J. R., S. Meier, A. Heiser, M. D. Mitchell, C. G. Walker, M. A. Crookenden, M. Vailati Riboni, J. J. Loor, and J. K. Kay. 2015. Effects of precalving body condition score and prepartum feeding level on production, reproduction, and health parameters in pasture-based transition dairy cows. J. Dairy Sci. 98:7164-7182.

Sordillo, L. M. 2016. Nutritional strategies to optimize dairy cattle immunity. J. Dairy Sci. 99:4967-4982.

Sørensen, J. T., and C. Enevoldsen. 1991. Effect of dry period length on milk-production in subsequent lactation. J. Dairy Sci. 74:12771283.

Van Soest, P. J. 1994. Nutritional Ecology of the Ruminant. 2nd edition. Comstock Pub., Ithaca, NY.

UK Government. 1986. Animals (Scientific Procedures) Act 1986. Accessed Dec. 19, 2016. www.legislation.gov.uk/ukpga/1986/14/ contents. Her Majesty's Stationery Office, London, UK.

Walsh, S. W., E. J. Williams, and A. C. Evans. 2011. A review of the causes of poor fertility in high milk producing dairy cows. Anim. Reprod. Sci. 123:127-138.

Weber, C., B. Losand, A. Tuchscherer, F. Rehbock, E. Blum, W. Yang, R. M. Bruckmaier, P. Sanftleben, and H. M. Hammon. 2015. Effects of dry period length on milk production, body condition, metabolites, and hepatic glucose metabolism in dairy cows. J. Dairy Sci. 98:1772-1785.

Weglarzy, K. 2009. Lactation productivity of dairy cows as affected by the length of preceding dry period. Anim. Sci. Pap. Rep. $27: 303-310$. 